\title{
Pragmatic Analyses of President Goodluck Jonathan's Concession Speech and General Muhammadu Buhari's Acceptance Speech: A Comparative Appraisal
}

\author{
Léonard A. Koussouhon \\ Department of English, Faculty of Arts Letters and Humanities (FLASH) Université d'Abomey-Calavi (UAC) Bénin \\ Servais D. Y. Dadjo (Corresponding author) \\ Department of English, Faculty of Arts Letters and Humanities (FLASH) Université d'Abomey-Calavi (UAC) Bénin \\ E-mail: dadservais@gmail.com
}

\author{
Received: 02-01-2016 \\ Accepted: 29-03-2016 \\ Advance Access Published: May 2016 \\ Published: 01-07-2016 \\ doi:10.7575/aiac.ijalel.v.5n.4p.12 \\ URL: http://dx.doi.org/10.7575/aiac.ijalel.v.5n.4p.12
}

\begin{abstract}
Drawing on Austin's (1962) Speech Act Theory, this paper investigates President Goodluck Jonathan's Concession Speech and General Muhammadu Buhari's Acceptance Speech for the purpose of examining the impacts of context and evaluating their effects on Nigerians. The application of Speech Act Theory to these political discourses has revealed valuable findings. To mention but a few, this study has shown a high proportion of claiming assertive speech acts in Jonathan's speech indicating thus how unity, stability and progress of Nigeria depends on Jonathan who has excellently proved this by conceding victory to his opponent Buhari. This has been confirmed by the very low proportion of these acts in Buhari's speech. Furthermore, Jonathan's acts of thanking, congratulating and praising indicate not only his high degree of recognition, attachment to peace and democracy but also his magnanimity whereas those of Buhari indicate his degree of recognition. Through the use of directive speech acts both Jonathan and Buhari have proved to be law abiding and peaceful. Through the use of commissive speech acts Jonathan has proved to be democratic and patriotic whereas Buhari has proved to be open, cooperative and democratic. The thoughtful performance of the different speech acts has enabled both speakers especially Jonathan to maintain peace and stability in Nigeria.
\end{abstract}

Keywords: Illocutionary act, locutionary act, perlocutionary act, pragmatics, speech act

\section{Introduction}

The study of language use has been widely carried by various scholars in different fields thus far. More importantly, presidential discourses have been the field of interest for many researchers for a long time. Indeed, presidential discourses are at the capstone in the organization and management of societies. Presidential discourses are messages addressed to a whole country, region, continent or even the whole world. It affects people at different levels of the organizational structures of societies. Specifically, this study focuses on Pragmatic Analyses of President Goodluck Jonathan's Concession Speech and General Muhammadu Buhari's Acceptance Speech. In fact, pragmatic approach of meaning analysis is quite important as it helps decode meaning from any type of speech. It must be noted that Speech Act Theory dates back to J. L. Austin's (1962) posthumous publication How to Do Things with Words. Speech Act Theory is central to pragmatics as it deals with acts performed in making utterances. This study applies Speech Act Theory to two selected political discourses delivered in a context of presidential elections in Nigeria. It aims at examining the impacts of context in these speeches and evaluating their effects on Nigerians. It also aims at decoding meanings from these speeches through a comparative appraisal. These discourses deserve critical analysis as they are central to the democratic process in Nigeria and more importantly they have been delivered at a highly critical moment during which the use of a single unsuitable utterance could lead voters to protest the results and undoubtedly the whole country to violence or civil war. This study also analyzes the sentence structures of the selected speeches on the basis of Eka's (2000) classification of sentence structures.

\section{Methodology}

Both quantitative and qualitative methods have been used to carry out this work. On the basis of quantitative method, two political speeches have been purposefully selected and Speech Act Theory has been applied to each of them. Indeed, the different speech acts have been identified and their corresponding statistics have been carefully provided for a thorough analysis. Thereafter, the statistical results found from the quantitative research have been qualitatively analysed, interpreted and more importantly, the reasons that underpin those statistics have been explained as well.

\section{Theoretical underpinning}

3.1 Defining pragmatics

The study of language use is highly important for these reasons among others: 
- $\quad$ Language use is social context dependent. This means that it needs communities to live in (Hasan 1985).

- Much more is communicated than is said or written (Yule 1996). This means that there are 'visible meanings' and 'invisible meanings.' 'Visible' meanings refer to what is communicated literally, to the conventional meaning of words whereas 'invisible' ones refer to speakers/writers' intended meaning, what they use words to mean in a specific context.

The meaning encoded in language cannot be rightly decoded out of its context since language is highly used in a social context. Thus, it is important to study language use and its context for the purpose of decoding language users' intended meaning. Taking into account the dimensions of meaning as communicated by a speaker, the interpretation made by a listener, the influence of the context, the invisible aspect of the meaning and the notion of distance, Yule (1996) defines pragmatics as:

(1) the study of speaker meaning.

(2) the study of contextual meaning.

(3) the study of how more gets communicated than is said.

(4) the study of the expression of relative distance (Yule, 1996: 3)

The above definitions highlight the importance of the study of language use for the purpose of decoding a speaker's intended meaning. All the above lead Yule (1996) to contend later that "in many ways, pragmatics is the study of 'invisible' meaning, or how we recognize what is meant even when it isn't actually said (or written)" (Yule, 1996: 127). Korta \& Perry (2006) excellently illustrate this while they assert that: "A diplomat who says 'yes' means 'maybe'; a diplomat who says 'maybe' means 'no'; and a diplomat who says 'no' is no diplomat" (Korta \& Perry, 2006). This clearly shows how much more is communicated than is said or written. On this basis, Korta \& Perry (2006) contend that 'pragmatics deals with utterances, by which we will mean specific events, the intentional acts of speakers at times and places, typically involving language' (Korta \& Perry 2006). Crystal (1987) puts particular emphasis on language users and the effects of their utterances on other participants as he defines pragmatics as: 'the study of language from the point of view of users, especially of the choices they make, constraints they encounter in using language in social interaction and the effects their use of the language has on other participants in the act of communication' (Crystal, 1985: 240). In the same line, Watson and Hill (1993) view pragmatics as 'the study of language from the view point of the user, especially the choices, the constraints he meets with in employing then use of the language and the effects the use has on the communication situation' (Watson \& Hill, 1993: 46). For Mey (2001), 'pragmatics studies the use of language in human communication as determined by the conditions of society' (Mey, 2001: 6). On his part, Leech (1983) simply views pragmatics as 'how language is used in communication' (Leech, 1983: 1).

The above definitions stress the importance of pragmatics and how it contributes to decode 'visible' and 'invisible meanings' conveyed by language users. For this reason, this study attempts to decode meanings from political discourses delivered in a context of presidential elections in Nigeria, by applying Speech Act Theory to President Goodluck Jonathan's Concession Speech and General Muhammadu Buhari's Acceptance Speech.

\subsection{Speech Act Theory}

Speech Act is, in Yule's (1997) terms, 'the act performed by a speaker with an utterance' (Yule, 1997: 132). As mentioned in the introduction, Speech Act Theory can be dated back to Austin's (1962) posthumous publication How to Do Things with Words, in which he distinguished between constatives and performatives: constatives are utterances that can be evaluated along a dimension of truth whereas performatives are utterances which cannot be said to be true or false but can be evaluated by a dimension of felicity. Furthermore, he classified linguistic acts into three components: locutionary act, illocutionary act and perlocutionary act. Locutionary act is 'performing the act of saying something' (Leech, 1983: 199). In Nordquist's (2015) terms, it is 'the act of making meaningful utterance' (Nordquist, 2015). Perlocutionary act is 'performing an act by saying something' (Leech, 1983: 199). According to Nordquist (2015), it is 'an action or state of mind brought about by, or a consequence of, saying something' (Nordquist (2015). Illocutionary act is 'performing an act in saying something' (Leech, 1983: 199). In other words, illocutionary act refers to 'a speaker's intention in delivering an utterance or to the kind of illocutionary act the speaker is performing' (Nordquist 2015). Austin (1962) categorized illocutionary act in five classes: verdictives, exercives, commissives, habitives and expositives. But Searle $(1969 ; 1976)$ proposed an alternative classification as follows:

i. Assertives: commit speakers to the truth of some proposition e.g. stating, claiming, reporting, announcing, describing, concluding, suggesting, predicting, etc.

ii. Directives: count as attempt to bring about some effect through the action of hearer e.g. requesting, ordering, demanding, questioning, pleading, inviting, begging, etc.

iii. Expressives: count as the expression of some psychological state e.g. thanking, apologizing, congratulating, appreciating, complaining, greeting, condoling, etc.

iv. Commissives: commit speakers to some future action e.g. promising, offering, swearing, threatening, warning, betting, guaranteeing, challenging, etc. to do something.

v. Declarations: speech acts whose successful performance brings about the correspondence between the propositional content and reality e.g. baptizing, resigning, dismissing, accepting, arresting, marrying, etc.

It is essential to note that Searle's classification has been adopted for the purpose of the analysis in this study. 


\section{Data analysis}

\subsection{Speech Act Types in the selected speeches}

The data of this study are President Goodluck Jonathan's Concession Speech and General Muhammadu Buhari's Acceptance Speech posted on April 1, 2015 by Nigerian Muse. The analysis has been carried out on the basis of Searle's (1975) Taxonomy of Illocutionary Acts. The table below displays the frequency of the different speech acts in both speeches.

Table 1. Frequency distribution of speech acts

\begin{tabular}{llccc}
\hline \multicolumn{1}{c}{ Speech acts } & \multicolumn{2}{c}{$\begin{array}{c}\text { President Goodluck Jonathan's } \\
\text { concession speech }\end{array}$} & $\begin{array}{c}\text { General Muhammadu Buhari's acceptance } \\
\text { speech }\end{array}$ \\
\cline { 2 - 5 } & Frequency & Percentage & Frequency & Percentage \\
\hline Assertive & 09 & $45 \%$ & 25 & $56.81 \%$ \\
\hline Directive & 02 & $10 \%$ & 05 & $11.36 \%$ \\
\hline Commissive & 02 & $10 \%$ & 05 & $11.36 \%$ \\
\hline Expressive & 07 & $35 \%$ & 07 & $15.90 \%$ \\
\hline Declarative & Nil & Nil & 02 & $04.54 \%$ \\
\hline Total & 20 & $100 \%$ & 44 & $99.98=100 \%$ \\
\hline
\end{tabular}

The graphs below clearly show the percentage distribution of illocutionary acts in both speeches.

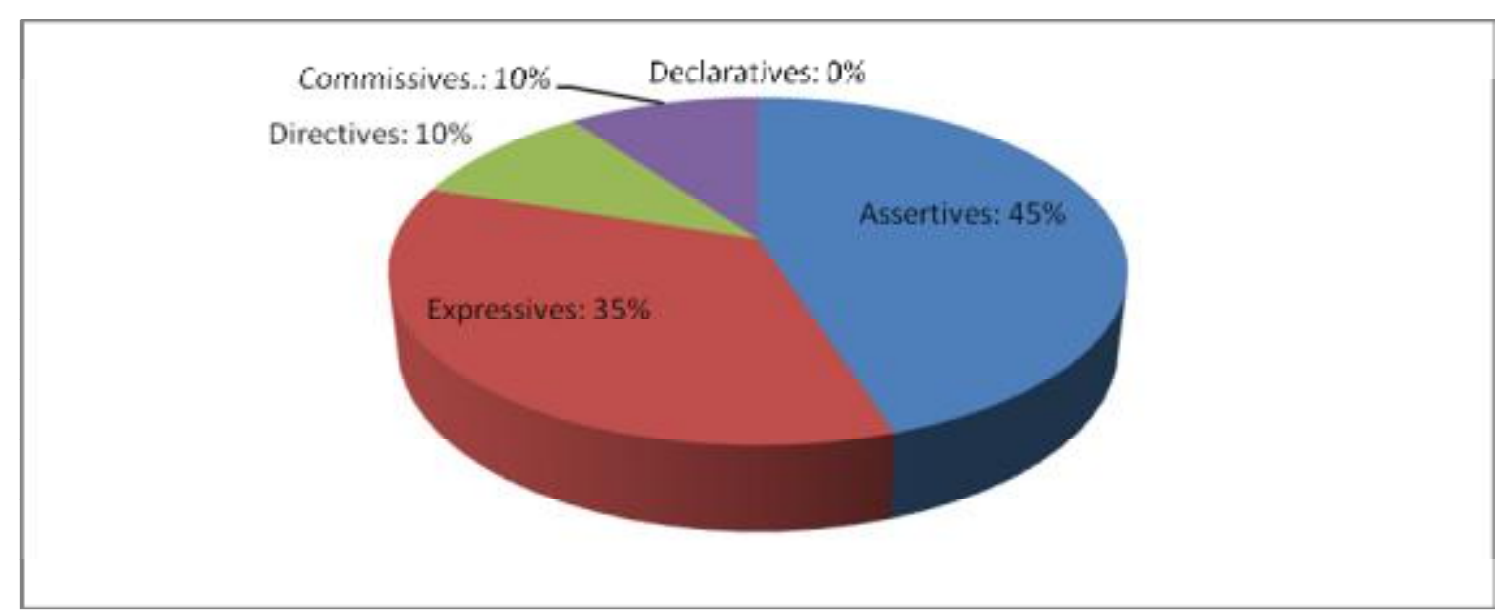

Figure 1. Percentage distribution of illocutionary acts in Speech 1

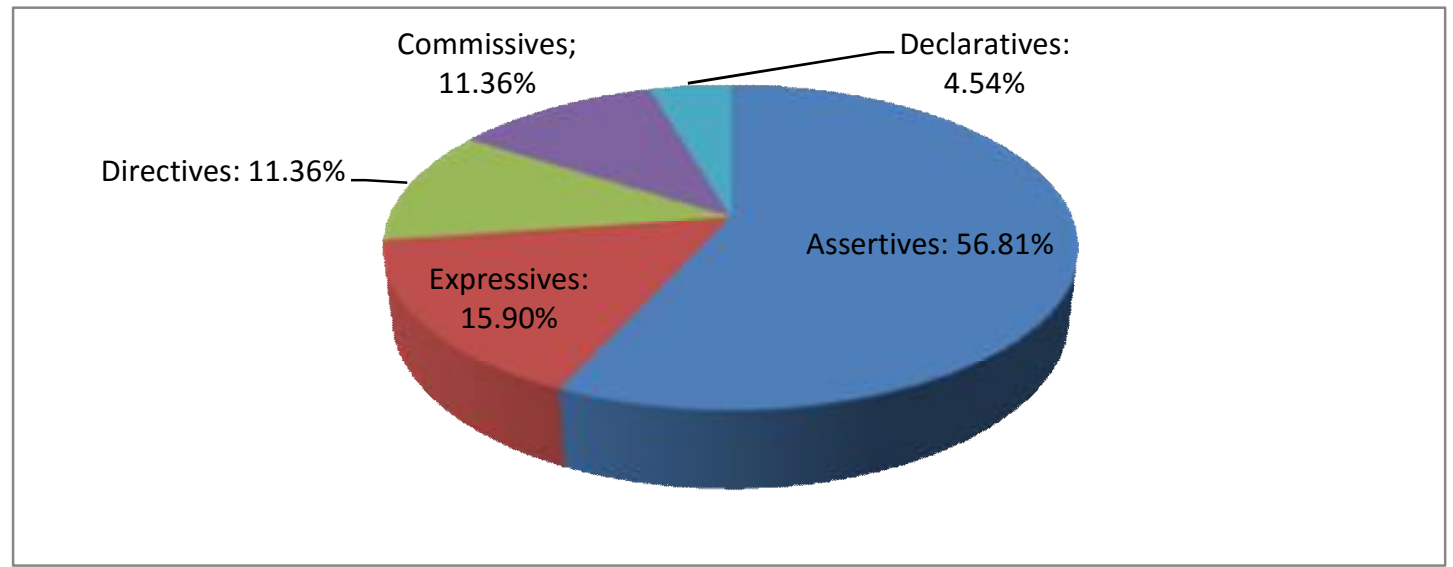

Figure 2. Percentage distribution of illocutionary acts in Speech 2

The speech act type with the highest frequency in both speeches is assertive. Indeed, assertive speech acts account for $45 \%$ and $47.72 \%$ respectively in Speech 1 and Speech 2. They comprise of stating, claiming, describing and reporting. The details are as follows:

\section{Assertive speech acts}

\section{Speech 1: President Goodluck Jonathan}

(3) I have kept my word [stating]. (4) I have also expanded the space for Nigerians to participate in the democratic process [claiming]...(7) As I have always affirmed, nobody's ambition is worth the blood of any Nigerian [stating]....(7) The unity, stability and progress of 
our dear country is more important than anything else [stating]...(12) Today, the PDP should be celebrating rather than mourning [stating] (13) We have established a legacy of democratic freedom, transparency, economic growth and free and fair elections [claiming]. (14) For the past 16 years, we have steered the country away from ethnic and regional politics [claiming]. (15) We created a Pan-Nigerian political party and brought home to our people the realities of economic development and social transformation [claiming]. (16) Through patriotism and diligence, we have built the biggest and most patriotic party in Nigerian history [claiming].

\section{Speech 2: General Muhammadu Buhari}

(2) At exactly 5:15 yesterday (Tuesday) evening, President Jonathan called to congratulate me on my victory [reporting]....(4) President Jonathan was a worthy opponent [stating]. (8) You stood in line patiently for hours; in the rain, in the sun and then in the dark to cast your votes [describing]. (9) Even when the vote was extended to Sunday in some places, you still performed your civic duties [describing]. (10) You did so peacefully [describing]. (11) You voted with your heart [describing]. (12) Your vote affirms that you believe Nigeria's future can be better than what it is today [stating]. (13) You voted for change and now change has come [stating]. (14) INEC has released the official result of the Presidential Election [stating]. (15) INEC has declared that I gained the most votes with the required spread and won this election [reporting]. (16) In a more profound way, it is you, Nigerians that have won [stating]. (17) The people have shown their love for our nation and their belief in democracy [stating]. (18) The declaration of INEC accurately reflects the will of the people [describing]. (20) While there might have been some logistical obstacles and irregularities associated with the exercise, the result shall stand as what the people want [stating]. (21) To me, this is indeed historic [stating]. (22) Most people will welcome the result because it is the one they voted for [stating]. (23) Others will literarily be disappointed [stating]. (25)This was a hard-fought contest [describing]. (26) Emotions were high [describing]. (30)We do this first by extending a hand of friendship and conciliation across the political divide [claiming]. (37)The eyes of the world were focused on us to see if we can vote in a peaceful way and carry out elections in an orderly manner [describing]. (38)We have proven to the world that we are a people who have embraced democracy and a people who seek a government by, for and for the people [stating]. (39) We have put one party state behind us [stating]. (41) CHANGE has come and a new day and a new Nigeria is upon us [stating]. (42) The victory is yours and the glory is that of our nation, NIGERIA [claiming].

As it appears, assertive speech acts are predominant in both speeches. Assertive speech acts in Jonathan's speech exclusively consist of stating [44.44\%] and claiming [55.55\%] of the total number of frequency of assertive speech acts whereas Buhari's speech presents not only stating [52\%] and claiming [08\%] but also describing [32\%] and reporting [08\%].

\section{Directive speech acts}

Directive speech acts are relatively low in both speeches. They account for 02 and 05 representing $10 \%$ and $11.36 \%$ respectively in Speeches 1 and 2. The details are as follows:

\section{Speech 1: President Goodluck Jonathan}

(6) Although some people have expressed mixed feelings about the results announced by the Independent National Electoral Commission (INEC), I urge those who may feel aggrieved to follow due process based on our constitution and our electoral laws, in seeking redress [urging]. (17) We must stand together as a party and look to the future with renewed optimism [demanding].

In Speech 1, directive speech acts consist of urging and demanding. Jonathan urges Nigerians who may feel aggrieved to follow due process based on their constitution and their electoral laws.

\section{Speech 2: General Muhammadu Buhari}

(1)Your Excellency, the Vice President elect, Professor Yemi Osinbajo, your Excellency, Chief Rotimi Amaechi, the Director General of APC Presidential Campaign, 2015, your Excellency, the former Governor of Edo State and National Chairman of our great party, your Excellency the Governor Imo State, Rochas Okorocha, your Excellency, the former Governor of Imo State, Dr Ogbonaya Onu, Your Excellency, the former Governor of Ekiti State, Engineer Oni, your Excellency the former Governor of Kwara, Bokola Saraki, your Excellency, the Speaker of the House of Representative, Honourable Aminu Tambuwal, Please, let me stand on existing protocol [requesting]. (3) For this, I want all Nigerians to join me in congratulating and appreciating Mr President for his statesmanship [inviting]. (24) I ask that we all be circumspect, respectful and peaceful in these times [inviting]. (27) We must not allow them to get the better of us [inviting]. (36) In the interim, I call on all Nigerians to be law abiding and peaceful [inviting]. 
Here, directive speech acts exclusively consist of requesting and inviting. Basically, Buhari invites Nigerians to be circumspect, respectful, peaceful and law abiding in those times.

\section{Commissive speech acts}

\section{Speech 1: President Goodluck Jonathan}

(2) I promised the country free and fair elections [promising]. (5) That is one legacy I will like to see endure [offering].

Jonathan has used only 02 commissive speech acts: promising and offering as illustrated in the above sentences (2) and (5). The expansion of the democratic process is the legacy Jonathan is offering to Nigerians through his Concession Speech.

\section{Speech 2: General Muhammadu Buhari}

(5) I extend my hand of fellowship to him [offering]....(7) He will receive nothing but cooperation and understanding from me, who led this nation to democracy [promising]....(35) We promise a robust and dynamic engagement with your countries in matters of mutual interest [promising]....(40) We have voted for a government that will serve and govern, but will never rule over you [promising]....(43) I will make a more formal address to the nation, later in the afternoon after I receive the certificate of return from the INEC [promising].

Buhari has used 05 commissive speech acts: offering and promising as illustrated in the above sentences (5), (7), (35), (40) and (43). Through these acts, Buhari offered not only his fellowship but also his cooperation and understanding to Jonathan.

\section{Expressive speech acts}

\section{Speech 1: President Goodluck Jonathan}

As the results displayed in Table 1 show, expressive speech acts rank second with $35 \%$ of frequency in Speech 1 . Below are the details:

(1)Fellow Nigerians, thank you all for turning out en-masse for the March 28 General Elections [thanking]....(9) I congratulate all Nigerians for successfully going through the process of the March 28th General Elections with the commendable enthusiasm and commitment that was demonstrated nationwide [congratulating]. (10) I also commend the Security Services for their role in ensuring that the elections were mostly peaceful and violence-free [congratulating]. (11) To my colleagues in the PDP, I thank you for your support [thanking]... (18) I thank all Nigerians once again for the great opportunity I was given to lead this country and assure you that I will continue to do my best at the helm of national affairs until the end of my tenure [thanking]....(19) I have conveyed my personal best wishes to General Muhammadu Buhari [praising]. (20) May God Almighty continue to bless the Federal Republic of Nigeria [praising].

Expressive speech acts in Speech 1 basically consist of thanking [42.85\%], congratulating [28.57\%] and praising [28.57\%].

\section{Speech 2: General Muhammadu Buhari}

(6)I look forward to meeting him soon, as we plan the transition from one administration to another [thanking]....(20) I thank all Nigerians who have made this day possible, our country has now joined the community of nations that have used the ballot box to physically change an incumbent president in a free and fair election [thanking].... (31)We hope and pray our friends in other parties reciprocate [praising]. (32) I thank all the members of the All Progressives Congress, the APC, for their commitment and their hard work through the formation of the party, the campaigns and the presidential elections [thanking]....(33) Let me equally express my appreciation to the media, civil society and security agencies for their selfless service [appreciating/congratulating]. (34 The international press and our friends abroad deserve a fair commendation for their support throughout the process [congratulating]....(44) May God Bless the Federal Republic of Nigeria [praising].

Here too, expressive speech acts basically consist of thanking [42.85\%], congratulating [28.57\%] and praising [28.57\%]. It appears that Buahari and Jonathan have performed exactly the same proportions of expressive speech acts.

\section{Declarative speech acts}

\section{Speech 2: General Muhammadu Buhari}

Declarative speech acts are completely nonexistent in Speech 1 whereas in Speech 2, they occur with the lowest frequency [04.54\%]. These are the details: (28) This is not the time for confrontation [declaring]. (29) This is a moment that we must begin to heal the wounds and work toward a better future [declaring].

\subsection{Sentence structure in the selected speeches}

Eka's (2000) classification of sentence structure has been adopted for the purpose of this analysis. Indeed, Eka's (2000) classifies sentences in five categories as follows: 'a simple sentence has one main clause and no subordinate clause. A 
compound sentence has two main clauses and no subordinate clause. A complex sentence has one main clause and at least one subordinate clause. A multiple sentence has at least three main clauses and no subordinate clause. A compound complex sentence has two main clauses and at least one subordinate clause.' (Eka, 2000: p 46) It must be noted that thorough sentence-by-sentence analyses of the selected speeches are presented in the appendices. Table 2 below displays the statistics of the different sentence types in both Speeches.

Table 2. Sentence types in Speeches 1 and 2

\begin{tabular}{llcccc}
\hline \multicolumn{1}{c}{ Types of sentences } & \multicolumn{2}{c}{$\begin{array}{c}\text { President Goodluck Jonathan's } \\
\text { concession speech }\end{array}$} & \multicolumn{2}{c}{$\begin{array}{c}\text { General Muhammadu Buhari's } \\
\text { acceptance speech }\end{array}$} \\
\cline { 2 - 5 } & \multicolumn{2}{c}{ Frequency } & Percentage & Frequency & Percentage \\
\hline Simple & 11 & $55 \%$ & 21 & $47.72 \%$ \\
\hline Compound & 01 & $05 \%$ & 02 & $04.54 \%$ \\
\hline Complex & 08 & $40 \%$ & 20 & $45.45 \%$ \\
\hline Compound-complex & Nil & Nil & 01 & $02.27 \%$ \\
\hline Multiple & Nil & Nil & Nil & Nil \\
\hline Total & 20 & $100 \%$ & 44 & $99.98=100 \%$ \\
\hline
\end{tabular}

The results show that simple sentences are predominant in both speeches with different proportions. In Jonathan's speech, they occur with a proportion of $55 \%$ whereas in Buhari's speech, they account for $47.72 \%$. Complex sentences follow with $40 \%$ and $45.45 \%$ respectively in Jonathan and Buhari's speeches. Compound sentences are very low in proportions in both speeches as they account for 5\% and $04.54 \%$ respectively in Jonathan and Buhari's speeches. Compound-complex sentences are nonexistent in Jonathan's speech whereas in Buhari's speech they are almost nonexistent with a frequency of $02.27 \%$. On the other hand, multiple sentences are nonexistent in both speeches.

\section{Discussion of the findings}

As the results of the speech acts analyses displayed in Table 1 show, assertive speech acts are predominant in both speeches. In fact, through stating assertive speech acts, Jonathan demonstrates how the unity, stability and progress of Nigeria is more important than anything else (7) and through claiming assertive speech acts, he puts emphasis on the expansion of the democratic process in Nigeria (4) as well as on its economic development and social transformation (15). The high proportion of claiming assertive speech acts indicates that unity, stability and progress of Nigeria depends on Jonathan and he has excellently proved this by conceding victory to his opponent Buhari. The very low proportion of claiming assertive speech acts in Buhari's Acceptance Speech clearly confirms this.

Through expressive speech acts, Jonathan thanks all Nigerians for their participation in the General Elections, the opportunity they gave him to lead them and particularly his colleagues in the PDP for their support. More importantly, he congratulates all Nigerians for the peaceful and violence-free elections and has even conveyed his personal best wishes to his opponent General Muhammadu Buhari. As far as Buhari is concerned, he has used expressive speech acts to thank all Nigerians and particularly the members of the All Progressives Congress (APC) for their commitment. Sentences (20) and (32) show this. As illustrated in sentences (33) and (34), he congratulates the media, civil society and security agencies for their selfless service and the international press for their support throughout the process. It must be noted that Jonathan's acts of thanking, congratulating and praising indicate his high degree of recognition as well as his attachment to peace and democracy. In a relatively same line, Buhari's acts of thanking, congratulating and praising indicate his high degree of recognition. Indeed, the detailed analysis of the expressive speech acts has revealed that Jonathan and Buhari have performed exactly the same proportions of expressive speech acts: thanking [42.85\%], congratulating [28.57\%] and praising [28.57\%]. On a superficial examination, this indicates their equally shared degree of gratefulness and attachment to their fellow citizens and their nation. But on a deep and close scrutiny, it must be pointed out that Jonathan neither has expressed disappointment, frustration nor sourness though he had lost the elections. This indicates that Jonathan is magnanimous and a peacemaker.

Directive speech acts enable Jonathan to urge Nigerians who may feel aggrieved to follow due process based on our constitution and our electoral laws. This indicates how law abiding and peaceful he is. Through directive speech acts exclusively consisting of requesting and inviting, Buhari invites Nigerians to be circumspect, respectful, peaceful and law abiding in those times. Sentences (27) and (36) illustrate these. This indicates how law abiding and peaceful he is.

Through commissive speech acts consisting of promising and offering, Jonathan would like to see the expansion of democratic process endure in Nigeria with free and fair elections. This indicates how democratic and patriotic he is. On his part, Buhari not only offers his fellowship to Jonathan but also commits to bring cooperation and understanding to him. More importantly, he commits to serve and govern but never to reign over / exercise sovereign power over Nigerians. All these indicate how open, cooperative and democratic Buhari is.

Declarative speech acts are completely nonexistent in Jonathan's speech. This suggests that he is no longer performing any action that brings about the correspondence between the content and the reality. This confirms the sincerity of his concession speech. On the other hand, declarative speech acts are present in Buhari's speech and concern passing sentence. Indeed, Buhari is trying to communicate to Nigerians that the moment is for healing the wounds and working for a better future for Nigeria rather than confronting. This indicates to what extent Buhari is attached to his fellow Nigerians. On the whole, the thoughtful performance of the different speech acts has enabled both speakers especially Jonathan to maintain peace and stability in Nigeria. 
On the other hand, the sentence structure analysis has revealed the predominance of simple sentences in both speeches indicating thus the degree of simplicity of both speakers; the high proportion of complex sentences $(40 \%$ and $45.45 \%$ respectively in Jonathan and Buhari's speeches) suggest their degree of complexity. The presence of compound sentences suggests the degree of open-ended collaboration of the speakers.

\section{Conclusion}

This study has attempted to decode meanings from Jonathan's Concession Speech and Buhari's Acceptance Speech through the application of Speech Act Theory. The analysis has revealed valuable findings. To mention but a few, the study has shown that assertive speech acts are predominant in both Speeches. The high proportion of claiming assertive speech acts in Jonathan's speech for instance, indicates that unity, stability and progress of Nigeria depends on Jonathan and he has excellently proved this by conceding victory to his opponent Buhari. More importantly, Jonathan's acts of thanking, congratulating and praising indicate not only his high degree of recognition, his attachment to peace and democracy but also his magnanimity whereas Buhari's acts of thanking and congratulating indicate his degree of recognition. Both Jonathan and Buhari have proved to be peaceful and law abiding through the use of directive speech acts. Through the use of commissive speech acts Jonathan has proved to be democratic and patriotic whereas as through the same acts, Buhari has proved to be open, cooperative and democratic. The thoughtful performance of the different speech acts has enabled both speakers especially Jonathan to maintain peace and stability in Nigeria. The absence of declarative act confirms the sincerity of Jonathan's concession speech whereas the presence of the same acts in Buhari's speech indicates to what extent Buhari is attached to his fellow Nigerians.

\section{References}

Austin, J. L. (1962). How to do things with words. Oxford: Clarendon Press. Buhari's Acceptance Speech. (2015, April 1). Nigerian Muse. Retrieved from http://www.nigerianmuse.com Crystal, D. (1987). The Cambridge Encyclopedia of Language. Cambridge: Cambridge University Press Eka, D. (2000). Elements of Grammar and Mechanics of English Language. Uyo: Samuf (Nigeria) Limited. Hasan, R. (1985). Linguistics, Language and Verbal Art, Oxford, Oxford University Press.

Jonathan's Concession Speech. (2015, April 1). Nigerian Muse. Retrieved from: http://www.nigerianmuse.com

Korta K. \& Perry, J. (2006). Pragmatics (Stamford Encyclopedia of Philosophy) Retrieved December 11, 2015 from http://www.grammar.about.com

Leech G. N. (1983). Principles of Pragmatics. London and New York: Longman.

Mey, J. (2009). Concise Encyclopaedia of Pragmatics $2^{\text {nd }}$ Edition. Oxford: Elsevier.

Nordquist, R. (2015). Glossary of Grammatical and Rhetorical Terms. Retrieved December 17, 2015 from http://www.plato.stamford.edu/entries/pragmatics

Searle, J. R. (1976). A Classification of Illocutionary Acts. Language in Society. Cambridge University Press. Retrieved from http://www.jstor.org/stable/4166848

Watson, J. R. \& Hill, A. (1993). A dictionary of Communication and Media Studies. London: Longman. Yule, G. (1996). Pragmatics. Oxford University Press.

Yule, G. (1997). The Study of Language. United Kingdom, Cambridge University Press.

\section{Appendices: Sentence structure in accordance with Eka's (2000) classification}

Keys: $\mathrm{S} 1=$ simple sentence; $\mathrm{S} 2=$ compound sentence; $\mathrm{S} 3=$ complex sentence; $\mathrm{S} 4=$ multiple sentence; $\mathrm{S} 5=$ compound complex sentence.

\section{President Goodluck Jonathan's concession speech (Wednesday, April 1, 2015)}

Fellow Nigerians, thank you all for turning out en-masse for the March 28 General Elections (S1. I promised the country free and fair elections (S1). I have kept my word (S1). I have also expanded the space for Nigerians to participate in the democratic process (S1). That is one legacy I will like to see endure (S2). Although some people have expressed mixed feelings about the results announced by the Independent National Electoral Commission (INEC), I urge those who may feel aggrieved to follow due process based on our constitution and our electoral laws, in seeking redress (S3). As I have always affirmed, nobody's ambition is worth the blood of any Nigerian (S3). The unity, stability and progress of our dear country is more important than anything else (S1). I congratulate all Nigerians for successfully going through the process of the March 28th General Elections with the commendable enthusiasm and commitment that was demonstrated nationwide (S3). I also commend the Security Services for their role in ensuring that the elections were mostly peaceful and violence-free (S3). To my colleagues in the PDP, I thank you for your support (S1). Today, the PDP should be celebrating rather than mourning (S3). We have established a legacy of democratic freedom, transparency, economic growth and free and fair elections (S1). For the past 16 years, we have steered the country away from ethnic and regional politics (S1). We created a Pan-Nigerian political party and brought home to our people the realities of economic development and social transformation (S3). Through patriotism and diligence, we have built the biggest and most patriotic party in Nigerian history (S1). We must stand together as a party and look to the future with renewed optimism (S3). I thank all Nigerians once again for the great opportunity I was given to lead this country and assure you that I will continue to do my best at the helm of national affairs until the end of my tenure (S3). I have conveyed my personal best wishes to General Muhammadu Buhari (S1). May God Almighty continue to bless the Federal Republic of Nigeria (S1) 
General Muhammadu Buhari's acceptance speech (Wednesday, April 1, 2015)

Your Excellency, the Vice President elect, Professor Yemi Osinbajo, your Excellency, Chief Rotimi Amaechi, the Director General of APC Presidential Campaign, 2015, your Excellency, the former Governor of Edo State and National Chairman of our great party, your Excellency the Governor Imo State, Rochas Okorocha, your Excellency, the former Governor of Imo State, Dr Ogbonaya Onu, Your Excellency, the former Governor of Ekiti State, Engineer Oni, your Excellency the former Governor of Kwara, Bokola Saraki, your Excellency, the Speaker of the House of Representative, Honourable Aminu Tambuwal, Please, let me stand on existing protocol (S1). At exactly 5:15 yesterday (Tuesday) evening, President Jonathan called to congratulate me on my victory (S1). For this, I want all Nigerians to join me in congratulating and appreciating Mr President for his statesmanship (S3). President Jonathan was a worthy opponent (S1). I extend my hand of fellowship to him (S1). I look forward to meeting him soon, as we plan the transition from one administration to another (S3). He will receive nothing but cooperation and understanding from me, who led this nation to democracy (S3). You stood in line patiently for hours; in the rain, in the sun and then in the dark to cast your votes (S3). Even when the vote was extended to Sunday in some places, you still performed your civic duties (S3). You did so peacefully (S1). You voted with your heart (S1). Your vote affirms that you believe Nigeria's future can be better than what it is today (S3). You voted for change and now change has come (S3). INEC has released the official result of the Presidential Election (S1). INEC has declared that I gained the most votes with the required spread and won this election (S3). In a more profound way, it is you, Nigerians that have won (S3). The people have shown their love for our nation and their belief in democracy (S1). The declaration of INEC accurately reflects the will of the people (S1). While there might have been some logistical obstacles and irregularities associated with the exercise, the result shall stand as what the people want (S3). I thank all Nigerians who have made this day possible, our country has now joined the community of nations that have used the ballot box to physically change an incumbent president in a free and fair election (S5). To me, this is indeed historic (S1). Most people will welcome the result because it is the one they voted for (S3). Others will literarily be disappointed (S1). I ask that we all be circumspect, respectful and peaceful in these times (S3). This was a hard-fought contest (S1). Emotions were high (S1). We must not allow them to get the better of us (S2). This is not the time for confrontation (S1). This is a moment that we must begin to heal the wounds and work toward a better future (S3). We do this first by extending a hand of friendship and conciliation across the political divide (S2). We hope and pray our friends in other parties reciprocate (S3). I thank all the members of the All Progressives Congress, the APC, for their commitment and their hard work through the formation of the party, the campaigns and the presidential elections (S1). Let me equally express my appreciation to the media, civil society and security agencies for their selfless service (S1). The international press and our friends abroad deserve a fair commendation for their support throughout the process (S1). We promise a robust and dynamic engagement with your countries in matters of mutual interest (S1). In the interim, I call on all Nigerians to be law abiding and peaceful (S1). The eyes of the world were focused on us to see if we can vote in a peaceful way and carry out elections in an orderly manner (S3). We have proven to the world that we are a people who have embraced democracy and a people who seek a government by, for and for the people (S3). We have put one party state behind us (S1). We have voted for a government that will serve and govern, but will never rule over you (S3). CHANGE has come and a new day and a new Nigeria is upon us (S3). The victory is yours and the glory is that of our nation, NIGERIA (S3). I will make a more formal address to the nation, later in the afternoon after I receive the certificate of return from the INEC (S3). May God Bless the Federal Republic of Nigeria (S1). 